\title{
TATA KELOLA PEMBINAAN PRAMUKA DI PERGURUAN TINGGI*
}

\author{
Ismail Suardi Wekke \\ Gugus Depan STAIN Sorong, Kwartir Cabang Kota Sorong, Papua Barat \\ Email: iswekke@gmail.com
}

\section{PENDAHULUAN}

Perguruan tinggi berada dalam dua posisi. Bagian dari Sistem Pendidikan Nasional, dan pada saat yang sama juga adalah struktur dari Gerakan Pramuka. Untuk itu, keduanya perlu diintegrasikan dan dikembangkan untuk memenuhi kedua posisi tersebut. Pendidikan tinggi perlu melakukan usaha-usaha untuk mengintegrasikan peluang yang tersedia di masyarakat (L. Anderson, 2014). Surat Keputusan Kwartir Nasional pertama kali terbit dengan Nomor 086 tahun 1987 tentang Penyelenggaraan Gugus Depan di Perguruan Tinggi menjadi payung hukum untuk sinkronisasi peran antara kedua posisi dalam satu lembaga.

Selanjutnya, pedoman secara teknis terwujud dalam Petunjuk Pelaksanaan Gugus Depan Gerakan Pramuka yang Berpangkalan di Kampus Perguruan Tinggi melalui Surat Keputusan Kwartir Nasional Gerakan Pramuka Nomor 180 A Tahun 2011. Namun, keberadaan SK tersebut memerlukan tindak lanjut sehingga bisa tersosialisasi ke seluruh wilayah Indonesia. Termasuk pula, diperlukan adanya pemahaman yang sama para pimpinan perguruan tinggi.

Perguruan tinggi di beberapa negara seperti Malaysia (Mohd Ali \& Borhandden Musah, 2012), Iran (Fadaee Khorasgani, 2008), Pakistan (Ellahi, Mushtaq, \& Bashir Khan, 2013), Saudi Arabia (Elyas \& Picard, 2013), India (Brewis, 2013), Mesir (Schomaker, 2015), dan kawasan Timur Tengah (Mourad \& El Karanshawy, 2013). Negara-negara tersebut menjadikan komponen lain yang justru bukan bagian perguruan tinggi secara langsung untuk memperkuat keberadaan perguruan tinggi.

Gerakan Pramuka tidak hanya dilaksanakan di pendidikan dasar dan pendidikan menengah. Tetapi juga perlu menjadi bagian dari pelaksanaan pendidikan tinggi. Apalagi ada peluang yang terbuka untuk mengakselerasi antara kepentingan Gerakan Pramuka dan Pendidikan Tinggi. Kerjasama menjadi kunci di abad 21. Tidak hanya bagi perguruan tinggi Indonesia saja tetapi juga untuk semua kawasan (Sugimura, 2012). Untuk itu,

\footnotetext{
* Disiapkan sebagai salah satu syarat dalam mengikuti Kursus Pelatih Dasar (KPD), Kwartir Daerah Bandar Lampung, 23 Februari s.d. 1 Maret 2018.
} 
makalah ini akan mengidentifikasi peluang untuk mengintegrasikan antara pramuka dengan lembaga perguruan tinggi.

\section{POSISI PRAMUKA DALAM SISTEM PENDIDIKAN NASIONAL}

Diterbitkannya Undang-Undang Republik Indonesia Nomor 12 Tahun 2010 tentang Gerakan Pramuka, menjadi landasan hukum untuk mengintegrasikan antara Gerakan Pramuka dengan Sistem Pendidikan Nasional. Dimana daya saing bangsa perlu dijadikan sebagai salah satu sasaran antara. Begitu juga dengan kondisi mutakhir perguruan tinggi yang memerlukan sinergi sehingga didapatkan adanya luaran berupa publikasi ilmiah. Keberadaan Pramuka akan strategis, dimana aktivitas yang dijalankan sepenuhnya merupakan kondisi pendidikan senyatanya.

Pembina Pramuka yang berprofesi sebagai dosen dan tenaga kependidikan di Perguruan Tinggi akan menyumbang bagi tersedianya portofolio dan bukti-bukti fisik yang diperlukan sebagai prasayarat untuk akreditasi. Oleh karena itu, jikalau integrasi antara pembinaan Pramuka dengan riset dalam skala mikro, akan memberikan kemanfaatan tidak hanya sampai pada tercapainya tujuan Gerakan Pramuka tetapi pada saat yang sama menempatkan perguruan tinggi bersanding dengan perguruan tinggi di kancah global secara seimbang.

Pada sisi lain, Pembina Pramuka juga dapat memenuhi keperluan Beban Kerja Dosen dan Kinerja Tenaga Kependidikan. Peran-peran seperti ini akan menjadi sebuah kesempatan pengembangan perguruan tinggi secara luas. Ada pertemuan dan kursus yang terjadwal di pelbagai tingkatan Pramuka. Keterampilan ini akan menjadi sebuah kesempatan bagi dosen dan tenaga kependidikan dalam memperkuat kapasitas. Sebagai contoh, Kursus Pelatih Dasar akan menjadi sebuah sinergi bagi dosen-dosen untuk mengenal perlbagai ragam dan teknik mengajar. Termasuk menggunakan media baik mutakhir maupun tradisional.

Publikasi dengan salah satu bentuknya adalah penerbitan artikel jurnal menjadi tuntutan. Maka, dengan adanya publikasi dosen yang menjadi pembina pramuka akan berfungsi ganda. Memenuhi beban kerja dosen, dan dapat digunakan untuk kenaikan pangkat, bahkan secara luas dapat menjadi kesempatan untuk menempatkan publikasi di jurnal-jurnal bereputasi melalui jaringan Gerakan Pramuka.

Demikian pula, ada keperluan akan akreditasi baik program studi maupun perguruan tinggi. Dalam menjalankan aktivitas pembinaan pramuka, paling tidak dapat 
memenuhi beberapa butiran sekaligus yaitu (1) sosialisasi perguruan tinggi untuk memenuhi keberlanjutan masukan mahasiswa, (2) pengayaan kurikulum dalam kaitan dengan Kerangka Kualifikasi Nasional Indonesia, (3) pembinaan bakat dan keterampilan mahasiswa, (4) pengembangan kapasitas dosen dan pembinan melalui pelatihan, kursus, atau pertemuan, (5) publikasi dosen, baik secara mandiri maupun (6) bersama mahasiswa, (7) pengabdian masyarakat, (8) kerjasama perguruan tinggi.

Memulai gagasan ini, maka koordinasi antara Pusat Pendidikan dan Latihan Nasional (PUSDIKLATNAS), dan Pusat Penelitian dan Pengembangan Nasional (PUSLITBANGNAS), dengan Gugus Depan yang berpangkalan di Perguruan Tinggi perlu dilakukan sejak awal. Selanjutnya, akan dipetakan kemungkinan apa yang bisa disinergikan diantara kedua bentuk kelembagaan yaitu Perguruan Tinggi dan Pramuka.

Pada saat yang sama PUSDIKLATDA dan PUSLITBANGDA di masing-masing Kwartir Daerah perlu menindaklanjuti dalam bentuk Rencana Aksi dalam skala regional. Olehnya, kesatuan kerja dan komunikasi dalam rangka menggerakan Pramuka sebagai pilar Sistem Pendidikan Nasional dapat disinergikan. Begitu pula dengan sosialisasi yang perlu dilakukan secara terus menerus. Ini untuk menepis anggapan (jikalaupun ada) bahwa Pramuka itu sekadar hanya menyanyi dan tepuk tangan. Padahal, ragam dan peluang untuk menjadikan Pramuka sebagai salah satu wahana untuk turut mendukung pengembangan perguruan tinggi terbuka luas. Bahkan ada prakarsa untuk mendirikan universitas yang dilandasi oleh Gerakan Pramuka (Ramsland \& Wheen, 2015).

Jika di perguruan tinggi secara khusus sudah ada Keputusan Bersama Direktur Jenderal Pendidikan Tinggi Departemen Pendidikan dan Kebudayaan, dan Ketua Kwartir Nasional Gerakan Pramuka di tahun 1981, maka perlu ditindaklanjuti berupa keputusan bersama dengan Kementerian Agama RI. Sehingga baik perguruan tinggi maupun satuan kerja lainnya di Kementeria Agama RI, dapat bersama-sama mengembangkan Satua Karya Amal Bhakti sehingga dapat terbentuk menjadi Andalan Nasional.

\section{PENGEMBANGAN PEMBINAAN PRAMUKA DAN TATA KELOLA PERGURUAN TINGGI}

Kementerian Agama RI dan Kwartir Nasional secara berkala melaksanakan Perkemahan Wirakarya (PW) yang diikuti 57 Perguruan Tinggi Keagamaan Islam. Dalam pengembangan PW di Kendari 2016, tidak hanya mengundang perguruan tinggi dari Direktorat Perguruan Tinggi Keagamaan Islam tetapi juga menghadirkan adik-adik dari 
Perguruan Tinggi Keagamaan Hindu, dll. Ini sebuah peluang untuk melakukan sinergi dan kolaborasi dalam satu kementerian. Termasuk dalam PW tersebut, kehadiran mahasiswa asing dari pelbagai Negara akan menjadi sebuah kesempatan dalam mendialogkan Islam di Indonesia sebagai salah satu model keberagamaan yang inklusif.

Pelaksanaan PW berikutnya di Riau akan menjadi kesempatan mengintegrasikan beberapa hal antara lain (1) kehadiran mahasiswa dalam pengabdian masyarakat, (2) pelibatan dosen dan mahasiswa dengan perguruan tinggi di Asia Tenggara untuk aktivitas yang memungkinkan dilaksanakan bersama, (3) kesempatan mengumpulkan data dan dapat diolah untuk publikasi pada saat kembali ke pangkalan masing-masing, (4) pertemuan dan diskusi, maupun seminar dengan target luaran buku bersama, dan (5) kerjasama perguruan tinggi baik dalam skala lokal, regional, nasional, maupun internasional.

Studi kasus berikutnya, berkaitan dengan Program Studi Pendidikan Guru Madrasah Ibtidiyah. Kualifikasi sarjana di program studi tersebut dapat dintegrasikan dengan mata kuliah Kepramukaan dengan sistem kredit semester sebesar 2 sampai 3 SKS. Begitu pula dengan Surat Keterangan Pelengkap Ijazah (SKPI) dapat diterbitkan setelah melalui pelatihan dalam Kursus Mahir Dasar (KMD). Maka, setiap mahasiswa PGMI diminta untuk mengikuti KMD sehingga saat bertugas di sekolah atau madrasah kemampuan mereka sudah memadai untuk langsung bertugas.

Kegiatan PW diprakarsai untuk memberikan kesempatan untuk mendialogkan beberapa hal antara lain penulisan karya ilmiah, kegiatan instruktur di alam terbuka (KIAT), dan sosialisasi keberadaan gugus depan melalui penggunaan media sosial, dan penulisan laman web berupa blog. Ini menjadi cerminan bahwa penggunaan media-media mutakhir perlu menjadi bagian dari akselerasi dalam Gerakan Pramuka. Tidak lagi, sekedar menggunakan media-media tradisional. Begitu juga dengan keragaman strategi dan teknik perlu dikuasai. Namun, media-media tradisional tidak ditinggalkan begitu saja, tetapi menjadi alternatif jikalau saja media mutakhir tidak dapat dioperasionalkan saat itu.

\section{MASA DEPAN PRAMUKA DI PERGURUAN TINGGI}

Mengintegrasikan antara perguruan tinggi dan Pramuka bukanlah pekerjaan yang mudah tetapi juga bukan sebuah langkah yang mustahil. Dialog dan komunikasi akan menjembatani keduanya sehingga harapan Gerakan Pramuka juga diwujudkan, pada saat yang sama perguruan tinggi paling tidak juga akan menjadi bagian dari dua hal yaitu Sistem Pendidikan Nasional dan pada sisi lain Gerakan Pramuka. 
Bahkan dalam menggalang kerjasama antarbangsa bisa melalui Pramuka. Dengan wadah Pramuka yang berada dalam jaringan Scoutisme Mondial, akan memberi kesempatan kepada perguruan tinggi untuk menjalin hubungan dengan perguruan tinggi luar negeri. Tidak saja di Asia Tenggara tetapi juga di benua lain. Secara berkala, ada kegiatan yang dilaksanakan dalam tingkat antarbangsa.

Lembaga Pengelola Dana Pendidikan (LPDP) perlu diajak untuk menyediakan pendanaan bagi anggota pramuka dalam bentuk Beasiswa Kader Bangsa. Ini sebagai sebuah kesempatan untuk mahasiswa yang selama ini sudah beraktivitas di Gerakan Pramuka, dan pada saat yang sama akan menjadi duta Bangsa dan Negara secara kultural. Mereka akan kembali ke wilayah masing-masing setelah mengalami perjumpaan dengan pelbagai kebudayaan. Dalam kesempatan ini, justru akan memperkuat identitas kebudayaan yang sudah ada sebelumnya.

Salah satu perguruan tinggi yang mengintegrasikan kedua kepentingan ini adalah Universitas Gadjah Mada. Melalui laman web http://pramuka.web.ugm.ac.id, pembinaan Pramuka dijalankan dengan slogan Sharing dan Membangun. Begitu juga dengan Pramuka di Universitas Padjajaran melalui laman web http://unpad.ac.id/universitas/lembagakemahasiswaan/pramuka-unpad. Pramuka di Universitas Padjajaran mulai diformalkan sejak tahun 1975. Secara aktif berpartisipasi dalam Jambore di Asia Tenggara dan juga Eropa.

Keberadaan PTKI Negeri yang berjumlah 57 lembaga, belum lagi ditambah dengan perguruan tinggi swasta yang semuanya merupakan Majelis Pembimbing Gugus Depan (MABIGUS) sebuah integrasi yang memungkinkan untuk menggerakkan potensi yang ada. Dengan demikian, akreditasi unggul bukanlah sebuah hal yang mustahil. Pramuka dalam kontesk ini akan menyumbang tidak hanya dalam pembinaan peserta didik tetapi secara luas akan sampai pada jenjang membangun daya saing bangsa. Maka, Pramuka sesungguhnya tidak dimaknai secara sempit saja tetapi sebuah gerakan yang terintegrasi, sinergi, dan kolaborasi, dengan semua kepentingan perguruan tinggi. Pendidikan Islam di Asia Selatan menjadikan Pramuka sebagai struktur pendidikan yang melekat (Park \& Niyozov, 2008). Demikian pula di Norwegia, kesefahaman dalam kaitan dengan hukum Islam justru tersosialisasi di Pramuka (Thomas \& Selimovic, 2015). Keduanya, justru mendekatkan dua kutub yang berbeda. Integrasi dan keselarasan akan memberikan hasil yang justru di luar dari harapan awal. 
Pendidikan tinggi di Indonesia tidak menjadi bagian yang terpisah dari masyarakat. Tantangan saat ini adalah kristalisasi eksklusifisme dan ego sektoral. Dengan demikian, memecahkan kebekuan ini, akan diperlukan langkah-langkah bersama dalam bentuk penyamaan persepsi. Sehingga sebuah aktivitas tidak hanya menghasilkan luaran untuk kepentingan itu saja tetapi juga berkaitan dengan keseluruhan aspek yang memungkinkan. Bonus tertinggi yang hendak dicapai adalah akreditasi. Dimana ini menjadi keperluan semua lembaga untuk menjamin mutu pelayanan (Schomaker, 2015).

Perguruan tinggi Islam di Indonesia berkembang dan bertumbuh dalam pelbagai bentuk (Roslan Mohd Nor \& Malim, 2014). Ini termasuk dalam kaitan dengan kesempatan untuk melakukan inovasi sesuai dengan konteks yang ada. Sehingga membangun budaya mutu tidak hanya berkaitan dengan apa yang sudah ada tetapi juga bisa dikaitkan dengan kesempatan dan peluang untuk melakukan ikhtiar. Dengan demikian, Gerakan Pramuka menjadi sebuah alternative untuk dikembangkan dalam konteks pendidikan tinggi terutama berkaitan dengan riset dan penjaminan mutu.

Pramuka merupakan kesempatan. Dengan adanya Pramuka justru menjadi sebuah peluang yang teramat luas. Jika ini dijadikan sebagai bagian dari sistem pendidikan di perguruan tinggi, maka sumber daya yang ada akan saling melengkapi. Gerakan Pramuka memiliki struktur yang sudah berkembang ke seluruh penjuru dan segala lini. Sehingga dengan Pramuka, justru akan memperkuat kapasitas dan keterampilan mahasiswa. Sebagaimana dalam pengguaan teknologi. Justru melalui Pramuka bisa saja berkembang dengan biaya yang relative terjangkau (Attaran \& Attaran, 2002).

Terakhir, sementara berkaitan dengan pengantarbangsaan perguruan tinggi, instrument Gerakan Pramuka dapat dijadikan sebagai salah satu bagian. Gerakan Pramuka sudah mengenal kerjasama pembina, dan pelatih. Demikian pula adanya latihan-latihan bersama. Jikalu ini dilaksanakan perguruan tinggi dengan mitra yang sudah ada dalam jaringan Pramuka akan menjadi sebuah capaian tersendiri. Untuk itu, integrasi antara komponen yang satu dengan komponen yang lain dapat terwujud jikalau ada kesepahaman.

\section{PENUTUP}

Gagasan-gagasan ini, masih dalam tahap awal. Sehingga bisa saja sudah terlaksana, namun penulis tidak memiliki informasi yang lengkap. Dengan demikian, diperlukan juga adanya diskusi yang terarah terutama dengan pemangku kepentingan dan juga pengalaman dari kakak-kakak Pembina yang selama ini sesungguhnya sudah berada di lapangan. 
Gerakan Pramuka dapat menjadi wadah eskpresi Tri Dharma Perguruan Tinggi. Salah satu kekuatan Gerakan Pramuka adalah kohesi sosial yang sudah terbangun. Termasuk adanya kwartir di semua tingkatan akan menjadi sarana komunikasi perguruan tinggi dengan masyarakat.

Pertanyaan-pertanyaan skeptis setelah menyelesaikan uraian makalah ini akan muncul diantaranya "apakah dapat terwujud? Tidakkah ini menjadi sebuah gagasan yang utopis?". Mungkin saja, tetapi bagian yang perlu dicermati adalah tidak aka nada sebuah pertumbuhan dan perkembangan kalau tidak dilandasi dengan keinginan bersama. Sementara itu, memisahkan pembinaan pramuka dengan tuntutan perguruan tinggi merupakan pekerjaan yang tidak saja berat tetapi juga memerlukan pembiayaan yang sangat berat. Dengan demikia, sudah perlu dilakukan langkah-langkah teknis untuk membangun akselerasi keduanya sehingga bisa menyumbang bagi performance perguruan tinggi kita dalam skala global.

\section{DAFTAR PUSTAKA}

Attaran, M., \& Attaran, S. (2002). Collaborative computing technology: the hot new managing tool. Team Performance Management, 8(1/2), 13-20. https://doi.org/10.1108/13527590210425059

Brewis, G. (2013). Education for service: social service and higher education in India and Britain, 1905-1919. History of Education Review, 42(2), 119-136. https://doi.org/10.1108/HER-07-2012-0020

Ellahi, A., Mushtaq, R., \& Bashir Khan, M. (2013). Multi campus investigation of academic dishonesty in higher education of Pakistan. International Journal of Educational Management, 27(6), 647-666. https://doi.org/10.1108/IJEM-03-20120039

Elyas, T., \& Picard, M. (2013). Critiquing of higher education policy in Saudi Arabia: towards a new neoliberalism. Education, Business and Society: Contemporary Middle Eastern Issues, 6(1), 31-41. https://doi.org/10.1108/17537981311314709

Fadaee Khorasgani, M. (2008). Higher education development and economic growth in Iran. Education, Business and Society: Contemporary Middle Eastern Issues, 1(3), 162-174. https://doi.org/10.1108/17537980810909788

L. Anderson, G. (2014). The reaction against conventional knowledge in higher education. On the Horizon, 22(1), 57-66. https://doi.org/10.1108/OTH-09-2013-0032

Mohd Ali, H., \& Borhandden Musah, M. (2012). Investigation of Malaysian higher education quality culture and workforce performance. Quality Assurance in Education, 20(3), 289-309. https://doi.org/10.1108/09684881211240330

Mourad, M., \& El Karanshawy, H. (2013). Branding Islamic studies: exploratory study in the Middle East. Journal of Islamic Marketing, 4(2), 150-162. https://doi.org/10.1108/17590831311329287

Park, J., \& Niyozov, S. (2008). Madrasa education in South Asia and Southeast Asia: current issues and debates. Asia Pacific Journal of Education, 28(4), 323-351. https://doi.org/10.1080/02188790802475372 
Ramsland, J., \& Wheen, A. (2015). The elite education of Lieutenant Arthur Wheen, MMnull. History of Education Review, 44(1), 85-98. https://doi.org/10.1108/HER01-2014-0001

Roslan Mohd Nor, M., \& Malim, M. (2014). Revisiting Islamic education: the case of Indonesia. Journal for Multicultural Education, 8(4), 261-276. https://doi.org/10.1108/JME-05-2014-0019

Schomaker, R. (2015). Accreditation and quality assurance in the Egyptian higher education system. Quality Assurance in Education, 23(2), 149-165. https://doi.org/10.1108/QAE-08-2013-0034

Sugimura, M. (2012). Possibility of East Asian integration through the regional networks and universities' cooperation in higher education. Asian Education and Development Studies, 1(1), 85-95. https://doi.org/10.1108/20463161211194487

Thomas, P., \& Selimovic, A. (2015). "Sharia on a Plate?" A critical discourse analysis of halal food in two Norwegian newspapers. Journal of Islamic Marketing, 6(3), 331353. https://doi.org/10.1108/JIMA-05-2014-0041 